\title{
The Phenomenon of Greek Traditional Dance Workshops in Greece: The Case of the Cultural Association "En Choro"
}

\author{
Niki Niora \\ School of Physical Education and Sports Science \\ National and Kapodistrian University of Athens \\ 41, Ethnikis Antistaseos str., 17237 Daphne \\ Athens, Greece \\ Maria I. Koutsouba \\ School of Physical Education and Sports Science \\ National and Kapodistrian University of Athens \\ 41, Ethnikis Antistaseos str., 17237 Daphne \\ Athens, Greece \\ Vasiliki Lalioti \\ School of Philosophy, Department of Music Studies \\ National and Kapodistrian University of Athens \\ University Campus (Panepistemiopolis) Zografou Area \\ Athens, Greece \\ Vasiliki Tyrovola \\ School of Physical Education and Sports Science \\ National and Kapodistrian University of Athens \\ 41, Ethnikis Antistaseos str., 17237 Daphne \\ Athens, Greece
}

\begin{abstract}
The participation of Greek dance teachers and members of dance groups in Greek traditional dance workshops has risen immensely during the last three decades in Greece. The explicit interest in obtaining additional knowledge in Greek traditional dances and the constant interaction of teachers-participants-organisers in the area where the workshop takes place, has created a particular characteristic "space" within the overall phenomenon of Greek traditional dance education. The aim of this paper is to provide an in-depth analysis of Greek traditional dance workshops in Greece by exploring the content, methods, and teaching styles of the longest-running workshop in


ethnographic research was carried out with its application to the dance research methodology. Data analysis was based on: a) teaching methods for Greek traditional dance; b) teaching styles proposed by Mosston and Ashworth (1994); and c) observation of the teaching process through the Cheffers Adaptation of Flanders Interaction Analysis System (CAFIAS). The findings of this research indicate that the teachers use a variety of teaching methods, while, the teaching process, as a whole, is dominated by the command style. Even though alternative teaching perspectives have been proposed during the last several years, dance teachers seem to disregard the new teaching directions or are reticent regarding the use of those new methods.
\end{abstract}

Keywords: Greek traditional dance, dance ethnography, dance education, dance workshops, dance teaching

\section{Introduction}

During the mid-70s, the first Greek traditional dance workshops (called $\sigma \varepsilon \mu \imath v \alpha$ ó $\alpha$ in Greece) make their appearance in Greece. They were mostly targeted at foreigners rather than at Greek dancers or dance teachers. In the late 70s, there was a growing interest in this type of workshops for foreigners in Greece, organised mostly by people involved in Greek traditional dance education. That decade can be defined as an early development era of the Greek traditional dance workshops. 
By that time, several Greek dance teachers had already participated in Greek traditional dance workshops organised abroad by individuals or universities (Loutzaki, 2010). Their example was followed by other Greek dance teachers, who started to organise workshops both in Greece and abroad.

In the beginning, those workshops functioned as entertainment spaces. The person responsible for the teaching was the organiser of the workshop, together with other dance teachers. Later on, we see the emergence of a one-week long "type of cultural camps" (Loutzaki, 2010, p. 77, ft. 39), in which in addition to the traditional dancing, the participants also received information about the dance repertoire, got into contact with traditional music bands, entertained themselves in local feasts and celebrations, as well as took part in improvised performances. In the early $90 \mathrm{~s}$, we can observe the nodal point of this phenomenon. During this period, there was a change regarding the structure and the content of these workshops: various instructors started to get invited to present a variety dance repertoire. Nowadays, these workshops are targeted mostly at the "professional dance teachers" (Loutzaki, 2010), and are systematised by following a specific organisational model: the instructors are being invited by the organisers several months before the beginning of the workshop.

Due to these developments, the workshop phenomenon has gradually evolved to become a large part of the Greek traditional dance phenomenon nowadays. In particular, the participation of Greek dance teachers and members of dance groups in Greek traditional dance workshops has spiraled during the last twenty years. This is due to the existing interest in obtaining additional knowledge regarding dance teaching as well as "new" dance repertoire. At the same time, an increasing number of dance teachers-instructors express their interest in promoting and sharing their dance knowledge by participating and teaching various dance workshops. The constant interaction between teachers, participants, and organisers at the place where the workshops are held, has shaped a new space within the context of Greek traditional dance teaching.

Thus, Greek traditional dance workshops constitute a characteristic phenomenon within the domain of Greek traditional dance education in Greece. This process led to the "legitimisation" and recognition of the dance teachers, who come from a variety of different contexts: they are researchers, who carry out fieldwork in local communities, or dancers, or both. As Loutzaki (2010) points out, "in their attempt to teach the local style (analysis, verbal descriptions, observations), they project their personal style as the local, which gradually evolves and is particularised into a style".

Based on the above observations, this paper examines the phenomenon of the Greek traditional dance teaching workshops in Greece. The review of the current literature showed that the phenomenon of the Greek traditional dance workshops has not attracted academic attention, at least to the extent that would reveal its multi-dimensional character. To fill this gap, the current study will examine a specific Greek traditional dance workshop, which is the longestrunning workshop in Greece. This workshop has been running uninterruptedly from 1992 until now, although under different auspices (1991-2010 under the auspice of the Ethnographic Centre of Teachers of Magnesia and from 2011 until today under the auspice of the newly established non-profit cultural association "En Choro").

\section{Aim of the study}

The aim of this study is to examine the case of Greek traditional dance workshops in Greece by looking at the content, methods, and the teaching style of the longest-running workshop in Greece, organised by the non-profit cultural association "En Choro".

\section{Methodology}

The methodological framework of this paper is based on the research carried out during the Greek traditional dance workshops organized by the cultural association "En Choro" in 2011, 2013, and 2014, entitled "Greek Traditional Dances Workshops" (Niora, 2017). The current methodology uses a combination of quantitative and qualitative research methods, including ethnographic research, which was carried out based on the principles of participant observation as it applies to the dance research (Buckland, 1999; Giurchescu \& Torp, 1991; Koutsouba, 1991, 1997, 1999; Lange, 1980, 1984; Tyrovola, 2008; Tyrovola, Karepidis, \& Kardaris, 2007). Systematic observations of the dance lessons and analysis of the teaching processes during the lessons was utilizing the following research models:

a) the teaching methods of Greek traditional dance (partial, holistic or mimetic method, method of common movement motifs, as well as morphological method, or a combination of the above (Demas, 2004, 2010; Karfis, Koutsouba, Tyrovola, \& Ziaka, 2010, 2012; Karfis, Tyrovola, Koutsouba, \& Ziaka, 2010, 2012a, 2012b; Karfis \& Ziaka, 2009; Mathe, Koutsouba, \& Likesas, 2008; Prantsidis, 2004; Serbezis „1995; Tyrovola, 1994, 2001, 2009, 2013a, 2013b; Tyrovola \& Koutsouba 2006; Vavritsas, 2008);

b) the teaching styles proposed by Mosston and Ashworth (1994); 
c) the observation of the teaching process through Cheffers Adaptation of Flanders Interaction Analysis System (CAFIAS), a reliable, valid, and objective system that has been tested within the Greek population (Cheffers, Mancini, \& Martinek, 1982). ${ }^{\mathrm{i}}$

The participants included 195 men and women (162 returning and new students, 24 instructors presenting a dance repertoire, 6 instructors presenting special issues, 2 external informants and the head of secretarial support).

This paper focuses on the analysis of the teaching process and the systematic observation of the lessons. For this purpose, nine videotaped teaching sessions were used, which were selected out of an overall of 25 sessions according to random sampling. To increase the accuracy and stability of the results, two systematic observations were carried out by two different observants for each videotaped teaching session. In order to ensure the correlation between the observants, the Speerman's Rho formula was used: $R h o=1-\frac{6 \Sigma d^{2}}{n\left(n^{2}-1\right)}$.

According to this formula, the higher the coefficient, the stronger is the correlation between the observants. In this case, the data of the qualitative research was used to interpret the results, obtained from the analysis of the teaching sessions and the systematic observation of the lessons.

\section{Content, methods, and teaching styles of the "En Choro" Greek traditional dance workshops}

It is important to first examine the terminological significance of the word "teaching", which in the context of the current study is utilized to refer to the transmission of knowledge from teachers to students.

The teaching session of the "En Choro" workshops is divided into two parts. The first part includes introduction, which encompasses information about local dance repertoire, accompanied by geographical, ethnographic, and historical data of the presented area. The second part is the main part of the workshop and includes a teaching session of the dance repertoire and has a longer duration.

During the Greek traditional dance workshops organised by the association "En Choro", we observed a great diversity of teachers' profiles with regards to their theoretical training, as well their previous fieldwork experience in this domain. This, in turn, led to an increased diversity of dance repertoire during the workshop. Based on our analysis, the dance teachers were divided into three different categories: a) Physical Education teachers, specialised in Greek traditional dance; b) local people who were not dance instructors; and c) local researchers/"empirical" teachers. Each category is presented below in detail.

\subsection{First (A) category of dance instructors: Physical Education teachers specialised in Greek traditional dance}

The selection criteria for this category of teachers included their teaching experience and research they had previously carried out in a community. These are the criteria also used by the organizers (Prantzidis, personal communication, May 11, 2013). From the data analysis, it became evident that all of the teachers in this category had carried out in situ recordings of local dances of the region they were asked to teach. Five out of nine teachers were brought up in the region, which was the focus of their teaching.

The first category of teachers included: nine (9) Physical Education instructors, who specialised in Greek traditional dance during their university degree. These dance teachers took part in the three seminars $(2011,2013$ and 2014) with eight (8) teaching sessions in total.

With regards to the content of the workshops, they included dances and songs from a wide variety of geographical regions, such as Eleftheres and Nikisiani (A1) (2014), Kythnos (A2) (2014) (See Figure 1), Assiros and Neochorouda (A3) (2013), Konitsa (A4) (2013), Aiani (A5) (2011), Eastern Rumelia (A6) (2011, 2013, 2014) (See Figure 2), Ak Bounar of Eastern Rumelia (A7) (2013), Tilos and Leros (A8) (2013). All teachers began their teaching sessions with geographical, ethnographic, and historical data, including information about local professions, music, and musicians, among other things. The data analysis indicated that seven out of nine teachers used holistic and partial (analytic) teaching method, whereas only two teachers adopted the morphological method. In total, eight (8) teaching methods were dominated by the command style (Mosston \& Ashworth, 2008). 


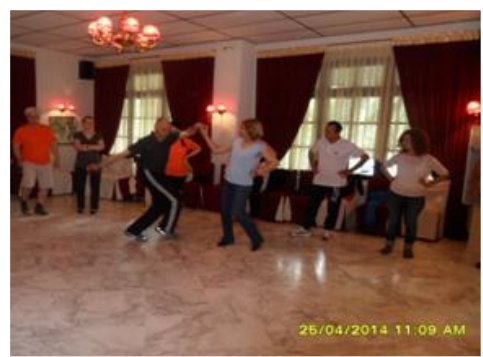

Figure 1: Kythnos island (A2) (2014)

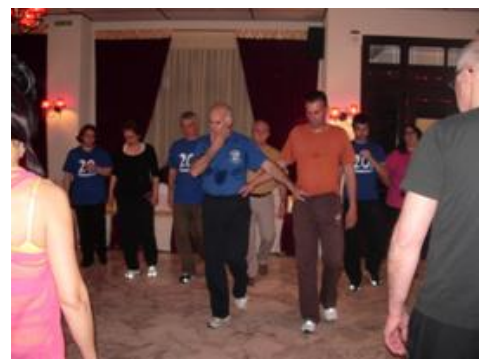

Figure 2: Eastern Rumelia (A6) (2011)

\subsection{Second (B) category of teachers: local dancers who are not dance teachers}

The organisers often invite local dancers to teach local dance repertoire, since they value the significance of the experiential relation of these people to local cultural heritage. The teaching sessions of this category mostly included dances and songs of two Greek islands, namely Karpathos (B1) (2014) (see Figure 3) and Kythnos (B2) (2011) (see Figure 4). Data analysis showed that those two (2) dance teachers presented both homogeneous and dissimilar elements. In particular, both of them were local dancers; one of them was a musician, but not a dance teacher (Karpathos), whereas the other instructor (Kythnos) partook in workshops in order to teach the local dance repertoire, without being systematically involved in dance teaching. The two teachers presented the dances through mimetic methods, assisted by the workshop's organisers and other participants (dance teachers). In total, two (2) teaching sessions were primarily dominated by the command style as described in Mosston \& Ashworth, 2008.

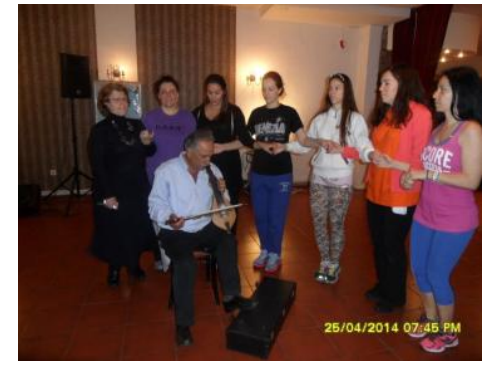

Figure 3: Karpathos island (B1) (2014)



Figure 4: Kythnos island (B2) (2011)

\subsection{Third (C) category of dance teachers: local researchers/ "empirical" teachers}

The third category of dance teachers consists of thirteen (13) teachers. In the context of the workshop, local dance teachers are often invited in a role of "experiential" dancers ii , as they are often referred to within the workshops space. These local instructors might also be researchers, presenting the repertoire of their community, or even the dance repertoire of neighbouring communities. With regards to the content, twelve (12) teaching sessions of this category included dances and songs from various places, such as Isvoarele (C1) (2014), Western Thrace (C2) (2011), Pontus area (C3) (2013), Chios island (C4) (2011), Asprokklisia (C5)(2013), Vamvakofyto (C6) (2011), Oinousses (C7) (2011), Sammakovio (C8) (2014) (See Figure 5), Leros (C9) (2014), Kleisoura (C10) (2014), Thesprotia (C11) (2011), and Roumlouki (C12) (2011) (See Figure 6).



Figure 5: Sammakovio (C8) (2014)

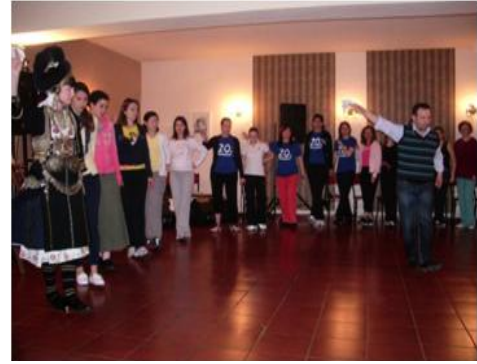

Figure 6: Roumlouki (C12) (2011)

Teachers, belonging to this category, usually teach dance in workshops or dance groups of local associations. Almost all of them were originally from the region, which was the study object of the workshop. With regards to the teaching methods, they used the holistic, the partial (analytical) method, and, to a lesser extent, the mimetic teaching method. They also presented other relevant data to the students about geographic and historical particularities of the presented region including local crafts, costumes, etc. 


\section{Discussion}

The analysis of the content, teaching methods, and the command style (Gibbons, 2007; Mosston \& Ashworth, 2008) used in the Greek traditional dance workshops have raised several important issues. Our study has found that the reproduction of knowledge during the workshops is promoted through a teacher-centred approach. Through the data collected during the systematic observation of the nine teaching sessions, utilizing the principles of the CAFIAS system and researcher's observations of the study participants, our study has found that even though dance teachers used different teaching methods, however, as a whole, their teaching sessions were mostly dominated by the command style (Mosston \& Ashworth, 2008), since, in all cases, the instructors' involvement in the teaching process was high, ranging from $70.4 \%$ to $99.51 \%$. This means that the teachers served as a model for the students, they took all the decisions, whereas students followed them and imitated their movements. The correlation of the observants was calculated according to the Speerman's Rho formula; both regarding teachers and participating students, a high percentage of correlation was found (see Table 1 and Table 2).

These results were expected to a certain extent, given that in those workshops the teachers are bound by very specific time limits in order to present their educational material. This explains the extended use of the command style on behalf of all teachers. However, this conclusion contrasts with the research data within the existing teaching field.

During the last years, research in the field of Physical Education has shown that teaching different sports and various types of dance becomes more effective through the use of styles that fall within the spectrum of either knowledge production (Alter, 2000; Cheesman 2011; Dania, 2012; Goudas \& Magotsiou, 2009; Macfadyen \& Bailey, 2002; Mouratidou, Goutza, \& Chatzopoulos, 2007; Pelclova, Frömel, Skalik, \& Stratton, 2008; Pitsi, Digelidis, \& Papaioannou, 2015; Salvara, Jess, Abbott, \& Bognar 2006; Siljamaki, Anttila, \& Saakslahti 2010), or of both reproduction and production of knowledge (Kulinna \& Cothran, 2003; Salvara \& Birón, 2002). However, it has been established that Physical Education teachers tend to use more often the styles that belong to the knowledge reproduction spectrum, such as the command style. This is because in this way they can supervise a big number of students, control and handle students more efficiently during the lesson in order to transmit the knowledge, while ensuring safety and effective use of time at class (Brady, 1998; Cothran et al., 2005; Cothran \& Kulinna, 2008; Curtner-Smith, Todorovich, McCaughtry, \& Lacon, 2001; Gibbons, 2007; Kulinna \& Cothran, 2003; Nieminen 1997, 1998). We observed a similar occurrence during the workshops.

With regards to the teaching methods, we have observed that all the methods were employed by all categories of dance teachers. More specifically, within the context of the workshops, the first category of teachers used holistic and partial methods, both individually and in combination (A1, A3, A4, A5, A6, A7, A8). In one case, the morphological method was employed (A2), a method that offers opportunity for student-centred learning and creativity ${ }^{\text {iii }}$.The application of the holistic and the partial methods were not coincidental. This is because all the dance instructors of this category were not recent graduates of the Physical Education Departments of various Universities (Athens, Thessaloniki, Komotini, Trikala), and had not been taught dance notation and morphology that were introduced to the Physical Education Departments later. Therefore, they have received this kind of knowledge from the Departments from which they have graduated $^{\text {iv }}$. It is not a coincidence that, in general, dance teachers are influenced by their own didactic experiences and the teaching methods of dance they were exposed to during their university education. This is what they would also adopt and apply at a later stage as professional dance teachers (Buck, 2006, as quoted in Dania, 2012; Warburton, 2008).

The second category (B) consists of local people, who are not dance teachers, and who are chosen by the organisers because of their experiential relationship they maintain with dance. In those cases, we have encountered that the two instructors (Karpathos (B1) and the Kythnos (B2) dance workshops), transmitted the local style because they are locals, regardless of their didactic skills. The lack of pedagogical principles with regards to dance teaching, i.e. whether the dance teacher knows what he/she teaches (didactics of movements, exercises, motives) and how he/she teaches it (Gibbons, 2007), as well as the use of other teaching methods apart from the mimetic method, complicated the transmission of the dance movement to the participants in case of these two instructors. For that reason, the organisers intervened in some cases by using the partial and holistic methods. Additionally, we have observed that even some participants with sufficient didactic experience intervened spontaneously during the workshop, in order to facilitate the "analysis" of the dance movement and, therefore, its transmission to the rest of the students.

At this point, it is worth mentioning that in the workshops organised by the association "En Choro", as well as on a broader national scale of other Greek traditional dance workshops, it is common to invite local dancers who are not dance teachers. Due to this, the lack of didactic capacity of some teachers is taken for granted from the start, being of secondary importance, and thus is widely accepted. 
It also noteworthy that the mimetic method, even combined in certain cases with another teaching method, was used by both dance teachers' categories (B and C), who were not Physical Education teachers. In other words, it was used by local dancers, who were not dance teachers and by local researchers that were "empirical" dance teachers. Moreover, mimetic method was used in the situations, where local dancers group were invited as guests to demonstrate specific local style of traditional dance. We see this occurrence in such dance workshops as Aiani (Kozani), Asprokklisia (Trikala) and Vamvakofyto (Serres).

It should be noted that even local researchers who were "empirical" dance teachers, belonging to the third category of teachers, had acquired teaching experience through their own dance teachers, hence, following the teaching methods of their own instructors as "experts" (Alter 2000; Dania, 2012; Loquet \& Ranganathan, 2010; Warburton, 2008; You, 2009).

Dance recordings and research that these dance teachers have carried out constitute additional sources for dance knowledge construction and the relevant repertoire. In their classes, they used the holistic $(\mathrm{C} 2, \mathrm{C} 4, \mathrm{C} 8, \mathrm{C} 9, \mathrm{C} 11$ and $\mathrm{C} 12)$, the partial-holistic (C3), as well as the mimetic-holistic method (C1, C5, C6, C7, C10).

Based on the above observations, we came to the conclusion that didactics of Greek traditional dance presents a wide spectrum of knowledge of the dance repertoire, the teaching methods, the theoretical framework with regards to dance, as well as recordings and research carried out by the professional and the "empirical" dance teachers. Moreover, dance teachers seem to play multiple simultaneous roles in Greek traditional dance education in Greece and abroad, such as local dancers, researchers, workshops' organisers, workshops' instructors, directors, stylists, interpreters of traditional songs and traditional musical instruments, presidents of cultural associations, and others (Avdikos, 2004; Charmanta, 2004; Filippou, Goulimaris, Serbezis, Pitsi, \& Genti 2009; Koutsouba, 2010b; Loutzaki, 1999, 2010b; Papakostas, 2001).

In addition, it is important to mention the introductory part of the workshops, during which all teachers without exemption often refer, either orally or with the use of PowerPoint presentations, video or photos to historical, ethnographic and folklore data, musical themes or traditional costumes. This constitutes an external verbal or nonverbal (such as video) feedback (Zervas, 2011). The external feedback (verbal or non-verbal) was still present during the second part of the workshop, which was dedicated to the learning of dance movements and contributed in the encouragement and motivation of the students for further improvement and correction of their mistakes (cf. Chiviacowsky \& Wulf, 2002; Magill, 2004; Zervas, 2011). Furthermore, during dance learning, in addition to the external feedback, each person has an internal closed system, which is activated and is providing constant internal feedback, from the movement control system in the brain to the peripheral nervous system, but also vice-versa, in order to bring the necessary adjustments in the movements, balance, coordination, and rhythm (Zervas, 2011).

It is a common knowledge that each dance instructor constitutes a role-model for students, since students' learning is based on the observation of instructor (Bandura, 1977, 1986). Students must follow, repeat, classify, codify, and memorise kinetic information, thus activating their long-term memory, in order to reproduce analogous dance patterns. It is not a coincidence that the command style as well as other styles belonging to the spectrum of reproduction of knowledge are connected and trigger the aforementioned functions with respect to old and new knowledge. Therefore, the dance teacher provides feedback, so the students could execute the kinetic patterns of the dance movement as perfectly as possible (Zervas, 2011), while the students react and adapt directly to the verbal and kinetic stimuli in order to achieve precision and accuracy of performance, synchronization, and uniformity (Mosston \& Ashworth, 2008).

During these workshops, a great variety of dances from different regions were taught and students were invited to deliver the multi-rhythmicity and rhythmic "multi-movement" observed in Greek traditional dance (Tyrovola, 2012), in a way that the integrated kinetic patterns could be created and assimilated. Since learning and execution of the complex skills required in traditional dance demand practice, time, and more kinetic energy until they are learned and automatised, the participants usually had the opportunity to repeat the learned dance repertoire both during the teaching session, as well as during the night feasts, in which organisers, instructors, and participants dance together.

However, it should be noted that the latest years' dance research had shown that the use of alternative didactic approaches (Bakka, 2015; Byra, 2000, 2002, 2006, 2015; Chatoupis 2007, 2009, 2010; Cothran et al., 2005; Digelidis, 2006; Emmanuel, Zervas, \& Vagenas, 1992; Kaufmann, 2006; Martinek, 1978; Martinek, Zaichkowsky, \& Cheffers, 1977; McNally, 2003; Theodorakou \& Zervas, 2003; Tyrovola \& Koutsouba, 2006; Wright \& Walkuski, 1995;Yu \& Kim, 2010) focus more on students' personal goals. On the other hand, alternative didactic practices are proposed during Greek traditional dance teaching sessions (Dania, 2012; Likesas, 2002; Likesas \& Zachopoulou, 2006; Likesas, Koutsouba, \& Tyrovola, 2009, 2010; Likesas, Koutsouba, Giosos, \& Tyrovola, 2015; Stivaktaki, Mountakis, \& Bournelli, 2010; Tyrovola, 2010; Venetsianou \& Leventis, 2010). 
For instance, during the workshop about Kythnos island dances, which used the morphological method (A2), dance teachers, who took part in the workshop as participants seemed to disregard the new didactic approaches and were reticent about the use of new methods.

In conclusion, during the last three decades, Greek traditional dance education moved from the community setting into the classroom. In this process, dance has perhaps lost some elements, yet may have acquired new ones, since the participants have to comply with the verbal and kinetic stimuli given by the instructors in order to achieve accuracy and precision of performance, as well as a uniform and synchronised performance (Mosston \& Ashworth, 2008). This transition of dance is not necessarily connected to the process of "deterioration" (Koutsouba, 1991, 2007, 2010a), since it may also be associated with the creative use of the traditional dance material within the new paradigm. While the dance workshops' organisers, instructors, and participants are not necessarily conscious of this transition they are the ones who facilitate the transformations of the form and the function of the dance per se, at the same time, believing that they transmit the "authentic" form of Greek traditional dance.

Table 1. Participation percentage of the teachers in the sessions. Correlation coefficient among the observants.

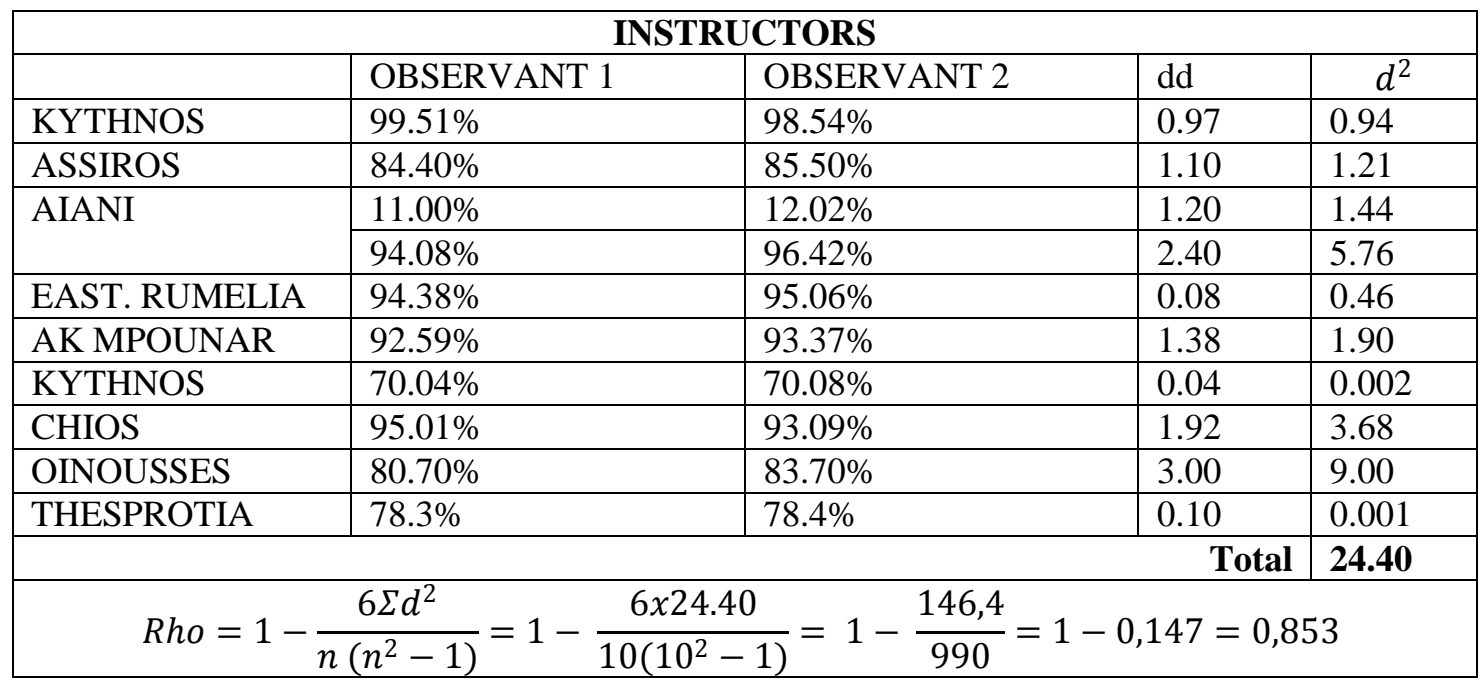

Table 2. Participation percentage of the participating students in the sessions. Correlation coefficient among the observants.

\begin{tabular}{|c|c|c|c|c|}
\hline \multicolumn{5}{|c|}{ PARTICIPATING STUDENTS } \\
\hline & OBSERVANT 1 & OBSERVANT 2 & $\mathrm{dd}$ & $d^{2}$ \\
\hline KYTHNOS & $60.98 \%$ & $60.99 \%$ & 0.01 & 0.00 \\
\hline ASSIROS & $56.80 \%$ & $56.13 \%$ & 0.67 & 0.44 \\
\hline \multirow[t]{2}{*}{ AIANI } & $84.25 \%$ & $84.25 \%$ & 0.00 & 0.00 \\
\hline & $59.33 \%$ & $59.66 \%$ & 0.33 & 0.109 \\
\hline EAST. RUMELIA & $44,52 \%$ & $45,80 \%$ & 0.28 & 0.078 \\
\hline AK MPOUNAR & $43.80 \%$ & $44.57 \%$ & 0.77 & 0.59 \\
\hline KYTHNOS & $51.07 \%$ & $50.6 \%$ & 0.47 & 0.22 \\
\hline CHIOS & $46.33 \%$ & $47.87 \%$ & 1.54 & 2.33 \\
\hline OINOUSSES & $51.4 \%$ & $49.9 \%$ & 1.50 & 2.25 \\
\hline THESPROTIA & $55.4 \%$ & $55.8 \%$ & 0.40 & 0.16 \\
\hline \multicolumn{4}{|c|}{ Total } & 6.17 \\
\hline \multicolumn{5}{|c|}{ Rho $=1-\frac{65 d^{2}}{n\left(n^{2}-1\right)}=1-\frac{6 \times 6.17}{10\left(10^{2}-1\right)}=1-\frac{37.02}{990}=1-0,0373=0,962$} \\
\hline
\end{tabular}




\section{References}

Alter, J. (2000). The transcultural adaptation of teaching methods from country of origin to an American university setting. Research in Dance Education, 1(1), 27-37.

Avdikos, E. (2004). Fairs and dance clubs: living and reviving of the tradition. In E. Avdikos (Ed.), Choreytika Eteroklita, Lykeio Ellinidon Dramas (pp. 203-212). Athens: Ellinika Grammata.

Bakka, E. (2015). Safeguarding of intangible cultural heritage - the spirit and the letter of the law. Musikk og tradisjon, 29, 135-169.

Bandura, A. (1977). Self-efficacy: Toward a unifying theory of behavioral change. Psychological Review, 84(7), 191215.

Bandura, A. (1986). Social foundations of thought and action. A social cognitive theory. Englewood Cliffs, N.J.: Prentice Hall.

Brady, F. (1998) A theoretical and empirical review of the contextual interference effect and the learning of motor skills. Quest, 50(3), 266-93.

Buckland, T. (Ed.). (1999). Dance in the field: Theory, methods and issues in dance ethnography. London: Macmillan Press.

Byra, M. (2000). A review of spectrum research. The contributions of two eras. Quest, 52, 229-245.

Byra, M. (2002). A review of spectrum research. In M. Mosston \& S. Ashworth, Teaching physical education (5th ed.) (pp. 319-335). San Francisco, CA: Benjamin Cummings.

Byra, M. (2006). Teaching styles and inclusive pedagogies. In D. Kirk, M. O'Sullivan, \& D. Macdonald (Eds.), Handbook of research in physical education (pp. 449-466). London: SAGE Publications.

Byra, M. (2015). A review of spectrum research: the contributions of two eras. Inquiries in Sport \& Physical Education 13(2), 77-100.

Charmanta, N. (2004). Transition of the dance from the square into the class and the show: thoughts, views and suggestions. In Avdikos, E. (Ed.), Choreytika Eteroklita, Lykeio Ellinidon Dramas (pp. 227-240). Athens: Ellinika Grammata.

Chatoupis, C. (2007). Decision making in physical education: theoretical perspectives. Studies in Physical Culture and Tourism, 14(2), 195-204.

Chatoupis, C. (2009). Contributions of the spectrum of teaching styles on research on teaching. Studies in Physical Culture and Tourism, 16(2), 193-205.

Chatoupis, C. (2010). Spectrum research reconsidered. International Journal of Applied Sports Sciences, 22(1), 80-96.

Cheesman, S. (2011). Facilitating dance making from a teacher's perspective within a community integrated dance class. Research in Dance Education, 12(1), 29-40. doi:10.1080/14647893.2011.554976

Cheffers, J. T. F., Mancini, V., \& Martinek, T. (1982). Systematic observation in teaching-interaction analysis. (Yannis Zervas, Trans.). Athens: University of Athens.

Chiviacowsky, S., \& Wulf, G. (2002). Self-controlled feedback: Does it enhance learning because performers get feedback when they need it? Research Quarterly for Exercise and Sport, 73(4), 408-415.

Cothran, D. J. \& Kulinna, P. H. (2008). Teachers' knowledge about and use of teaching models. Physical Educator, 65, 122-133.

Cothran, D. J., Kulinna, P. H., Banville, D., Choi, E., Amade-Escot, C., Macphail, A., Macdonald, D., Richard, J. F., Sarmento, P., \& Kirk, D. (2005). A cross-cultural investigation of the use of teaching styles. Research Quarterly for Exercise and Sport 76(2), 193-201.

Curtner-Smith, D.M., Todorovich, R.J., McCaughtry, N.A., \& Lacon, S.A. (2001). Urban teachers' use of productive and reproductive teaching styles within the confines of the national curriculum for physical education. European Physical Education Review, 7(2), 177-90.

Dania, A. (2013). From symbols to movement. Effects of the laban-notation method on learning Greek traditional dance. (Doctoral dissertation, National and Kapodistrian University, Athens.

Demas, I. (2004). Music and dance folk tradition: Greek students' dance habits. (2nd ed.). Athens: ArtWork.

Demas, I. (2010). On the teaching of Greek traditional dance. In Demas. I., Tyrovola, V. \& Koutsouba, M (Eds.), Greek traditional dance. Theorisations for its discourse, writing and teaching (pp. 43-64). Athens: selfpublished.

Digelidis, N. (2006). Extending the spectrum: An in depth analysis of the teaching styles taxonomy. Inquiries in Sport \& Physical Education 4(2), 131-147. Retrieved from http://www.pe.uth.gr/hape/images/stories/emag/vol4_2/hape097.pdf 
Emmanuel, C., Zervas, Y., \& Vagenas, G. (1992). Effects of four physical education teaching methods on development of motor skill, self-concept, and social attitudes of fifth - grade children. Perceptual and Motor Skills, 74, 1151-116.

Filippou, F., Goulimaris, D., Serbezis, V., Pitsi, A., \& Genti, M. (2009). The role of dance associations in the evolution of Greek music - dance tradition: The example of "Sygathistos" dance in Velvedo of Kozani. Inquiries in Sport \& Physical Education, 7(1), 30-38.

Gibbons, E. (2007). Teaching dance: The spectrum of styles. Bloomington, IN: Author House.

Giurchescu, A. \& Torp, L. (1991). Theory and methods in dance research: A European approach to the holistic study of dance. Yearbook for Traditional music, 23, 1-10.

Goudas, M., \& Magotsiou, E. (2009). The effects of a cooperative physical education program on students' social skills. Journal of Applied Sport Psychology, 21(3), 356-364.

Karfis, V., Koutsouba, M., Tyrovola, V., \& Ziaka, M. (2010). A proposal for the teaching of Greek Folk Dance. Applying the structural-morphological method of teaching to the didactics of the Cretan dances. Paper presented at the 18th World Conference of Physical Education and Sports. Komotini, Greece. Abstract retrieved from http://www.phyed.duth.gr/undergraduate/images/files/congress/2010/oral10/Dance.pdf

Karfis, V., Tyrovola, V., Koutsouba, M., \& Ziaka, M. (2010). Compositions and re-compositions in Greek folk dance. Structural/morphological and typological analysis of the Cretan dances. Paper presented at the 18th World Conference of Physical Education and Sports. Komotini, Greece. Abstract retrieved from http://www.phyed.duth.gr/undergraduate/images/files/congress/2010/oral10/Dance.pdf

Karfis, V., Tyrovola, V., Koutsouba, M., \& Ziaka, M. (2012a). Contrasting patterns in traditional greek dancing. Ways of composing and constructing the dancing form, in the communities of Drama and Serres, Macedonia. Paper presented at the 20th World Conference of Physical Education and Sports. Komotini, Greece. Abstract retrieved

from http://www.phyed.duth.gr/undergraduate/images/files/congress/2012/oral12/Dance_Sciences.pdf

Karfis, V., Tyrovola, V., Koutsouba, M., \& Ziaka, M. (2012b). Traditional stereotypes and creativity: the case of the dance "Baitouska". Kinisiologia, 5, 29-32. Retrieved from http://kinisiologia.phed.uoa.gr

Karfis, V., \& Ziaka, M. (2009). The Greek traditional dance in education. Teaching suggestions. Thessaloniki: Vivliodiaplous.

Kaufmann, K. A. (2006). Inclusive creative movement and dance. Champaign, IL: Human Kinetics.

Koutsouba, M. (1991). Greek dance groups of Plaka: A case of "airport” art (Master's thesis). University of Surrey, UK.

Koutsouba, M. (1999). 'Outsider' in an ' inside' world, or dance ethnography at home. In T. J. Buckland, (Ed.), Dance in the field: theory, methods, and issues in dance ethnography (pp.186-195). New York: St. Martin's Press.

Koutsouba, M. (2007). The teaching of Greek folk dance in the modern education context. In Popular Culture and Education, Proceedings of 1st International Education Conference.

Koutsouba, M. (2010a). The teaching of Greek traditional dance in the contemporary educational context. In Demas. I., Tyrovola, V. \& Koutsouba, M., Greek traditional dance. Theorisations for its discourse, writing and teaching (pp. 101-126). Athens: self-published.

Koutsouba, M. (2010b). The Greek traditional dance at its "first" and "second" existence. Views and concerns. Paper presented at the 18th World Conference of Physical Education and Sports. Komotini, Greece. Retrieved from http://www.phyed.duth.gr/undergraduate/images/files/congress/2010/oral10/Dance.pdf

Kulinna, P.H., \& Cothran, D.J. (2003). Physical education teachers' self-reported use and perceptions of various teaching styles. Learning and Instruction, 13, 597-609.

Lange, R. (1980). The development of anthropological dance research. Dance Studies, 4, 1-36.

Lange, R. (1984). Guidelines for fieldwork on traditional dance methods and checklist. Dance Studies, 8, 7-48.

Likesas, G. (2002). Teaching Greek traditional dance in primary school with the method of Music and movement education (Doctoral dissertation). Aristotle University of Thessaloniki, Greece.

Likesas, G., Koutsouba, M., Giosos, I., \& Tyrovola, B. (2015). The Effectiveness of a Theatrical Playing Program in the Process of Learning Greek Traditional Dance in Elementary School Students. Woman \& Sport, 9, 7-56.

Likesas, G., Koutsouba, M., \& Tyrovola, V. (2009). Creativity as an approach and teaching method of Greek traditional dance in secondary education. Studies in Physical Culture \& Tourism, 16(2), 207-214.

Likesas, G., Koutsouba, M., \& Tyrovola, V. (2010). Comparison of teacher and child-centred methods of teaching Greek traditional dance in elementary education. International Journal of Physical Education, 47(3), 25-32.

Likesas, G., \& Zachopoulou, E. (2006). Music and movement education as a form of motivation in teaching Greek traditional dances. Perceptual and Motor Skills, 102, 552-562. 
Loquet M., \& Ranganathan M. (2010). Content knowledge in teaching, an investigation into an adequate 'milieu' for teaching dance: The case of Indian dance in France. European Physical Education Review, 16, 65-79. doi:10.1177/1356336X10369198

Loutzaki, I. (1999) The Association as milieu for dance activity. In Music of Thrace. An interdisciplinary approach. Evros. (pp.193-247). Athens: The Friends of Music-Research Programme 'Thrace'.

Loutzaki I. (2010a). Greek dance - Local traditions and their representations. In Dance Anthropology. Five essays (pp. 77-134). Athens: Faculty Music Studies. University of Athens.

Loutzaki, I. (2010b). Lykeio Ellinidon. From "Big National Celebrations" to performance shows with artistic pretensions. In P. Kavouras, (Ed.), Folklore and Tradition. Issues of re-presentation and performance of music and dance (pp. 113-130). Athens: Nissos Publications.

Macfadyen, T., \& Bailey, R. (2002). Teaching physical education 11-18: Perspectives and challenges. London: Continuum.

Magill, R.A. (2004). Motor learning and control: Concepts and applications. New York: McGraw-Hill.

Martinek J., Zaichkowsky D., \& Cheffers J.T.F. (1977). Decision making in elementary age children: Effects on motor skills and self concept. Research Quarterly, 48(2), 349-357.

Martinek T.J. (1978). Decision-sharing in elementary school children: Effects on body-concept and anxiety, Perceptual and Motor Skills, 47, 1015-1021.

Mathe. D., Koutsouba, M., \& Likesas, G. (2008). Critical review of the proposed teaching methods of Greek traditional dance in Greece. Proceedings of the 22nd World Congress on Dance Research, 1-17. Athens: International Dance Council-CID.

McNally, J. (2003). The effects of immediate supervisory feedback using audiocuing on the interaction between students and preservice physical education teachers. (Master's thesis). Ithaca College Theses, 177. Retrieved from https://digitalcommons.ithaca.edu/ic_theses/177

Mosston, M., \& Ashworth, S. (1994a). Teaching physical education. Thessaloniki: Salto.

Mosston, M., \& Ashworth, S. (1994b). Teaching physical education. New York: Macmillan College.

Mosston, M., \& Ashworth, S. (2008). Teaching physical education (1st online ed.). Retrieved from http://www.spectrumofteachingstyles.org/pdfs/ebook/Teaching_Physical_Edu_1st_Online_old.pdf

Mouratidou, K., Goutza, S., \& Chatzopoulos, D. (2007). Physical education and moral development: An intervention programme to promote moral reasoning through physical education in high school students. European Physical Education Review, 13(1), 41-56.

Nieminen, P. (1997). Participation profiles and socialisation into dance among non-professional dancers. Sport, Education and Society, 2(2), 221-234.

Nieminen, P. (1998). Four dance subcultures. A study of non-professional dancers' socialization, participation motives, attitudes and stereotypes. Jyväskylä: Jyväskylä University Printing House.

Niora, N. (2017). Learning and administration of Greek traditional dance. The case of a timeless seminar in Greece (Doctoral dissertation). DPESS, University of Athens, Athens.

Papakostas. C. (2001). Dance from the community onto the stage: techniques and controversies. Proceedings of the 2nd Hellenic Conference on Folk Culture "Melody, Speece, Movement". Serres: TEFAA Serron.

Pelclová, J., Frömel, K., Skalik, K., \& Stratton, G. (2008). Dance and aerobic dance in physical education lessons: The influence of the student's role on physical activity in girls. Acta Universitatis Palackianae Olomucensis. Gymnica 38(2), 85-92. Retrieved from https://www.gymnica.upol.cz/pdfs/gym/2008/02/09.pdf

Pitsi A., Digelidis N., \& Papaioannou A. (2015). The effects of reciprocal and self-check teaching styles in students' intrinsic-extrinsic motivation, enjoyment and autonomy in teaching traditional Greek dances. Journal of Physical Education and Sport, 15(2), 352-361.

Prantsidis, G. (2004). Dance in Greek tradition and its teaching. Aiginion: Ekdotiki Aiginion.

Salvara, I.M., \& Birón, N.E. (2002) Teachers' use of teaching styles: A comparative study between Greece and Hungary. International Journal of Applied Sport Sciences, 14(2), 46-69.

Salvara, M.I., Jess, M., Abbot., \& Bognar, J. (2006). A preliminary study to investigate the influence of different teaching styles on pupil's goal orientations in physical education. European Physical Education Review, 12, 51-74.

Sermpezis, V. (1995). Comparative study of Greek traditional dance teaching methods for kids between 9 and 11 years old (Doctoral dissertation). TEFAA, Democritus University of Thrace, Komotini.

Siljamäki, M., Anttila E., \& Sääkslahti A. (2010). Pedagogical conceptions of Finnish teachers of transnational dances. Cases: African dance, Oriental dance and Flamenco. Nordic Journal of Dance, 2, 39-55. 
Stivaktaki, C., Mountakis, C., \& Bournelli, P. (2010). The effect of a cross- curricular study programme in physical education on the attitudes and perceptions of Greek children towards traditional (folk) dance in the first year of secondary school. Research in Dance Education, 11(3), 193-211.

Theodorakou, K., \& Zervas, Y. (2003). The effects of the creative movement teaching method and the traditional teaching method on elementary school children's self-esteem. Sport Education and Society, 8(1), 91-104.

Thomas, J. R. \& Nelson, J. K. (2003). Research methods in physical activity. (K. Karteroliotis, Trans.). Athens: Paschalidis Medical Publications.

Tyrovola, V. (1994). The dance "Sta Tria" in Greece: Structural - morphological and typological approach. (Doctoral dissertation, University of Athens, Department of Music, Athens, Greece).

Tyrovola, V. (2001). Greek dance - a different approach. Athens: Gutenberg Editions.

Tyrovola, V. (2009). Melody, rhythm \& dance, A different methodological proposal in the approach of dance style. Science of Dance, 3, 48-84. Retrieved from http://elepex.gr/index.php/el/content/volume3

Tyrovola, V. (2008). Influences and cultural crosses in the dance tradition between Greece and the Balkans. The case of the 'Hasapiko dance'. Studia Choreologica, 10, 53-95.

Tyrovola, V. (2010). Music and dance rhythm, self-expression and aesthetic education. Conditions and methods of creating an artistic choreographic composition and improvisation. In M. Argyriou (Ed.), Music Pedagogy in the 21st century. Challenges, problems and perspectives, Vol. 2 (pp. 12-28). Athens: E.E.M.A.P.E. Retrieved from www.primarymusic.gr

Tyrovola, V. (2013a). Choreogical Issues B'. On dance... Seven working assumptions on science, art and dance form. Athens: Tyrovola, V.K.

Tyrovola, V. (2013b). Choreogical Issues B'. On dance... For a scientific substantiation of dance: Positions, contrapositions and compositions. Athens: Tyrovola, V.K.

Tyrovola, V., Karepidis I., \& Kardaris, D. (2007). Pontian dances. Past and present. Structural-morphologic and typological approach. Searches at Physical Education and Sports Science, 5, 1-24.

Tyrovola, V., \& Koutsouba, M. (2006). The morphological method of teaching Greek traditional dance. The example of the dances of Pontos. Music in Primary Education, 1, 19-32.

Vavritsas, N. (2008). Traditional dances and their teaching. Thessaloniki: Vavritsas N. Editions

Venetsanou, F. \& Leventis, C. (2010). The Greek traditional dance for preschool children. 40 lessons for the integral development of the children. Athens: Athlotipo.

Warburton, E. C. (2008). Changes in dance teachers' beliefs about critical-thinking activities. Journal of Education and Human Development, 2(1), 1-16.

Wright S., \& Walkuski J. (1995). The use of systematic observation in physical education. Teaching and Learning, $16(1), 65-71$.

You, J. (2009). Teaching beginning dance classes in higher education: Learning to teach from an expert dance educator. International Journal of Education \& the Arts, 10(23), 1-23. Retrieved from http://www.ijea.org/v10n23

Yu, J. H., \& Kim, J. K. (2010). Patterns of interactions and behaviors: Physical education in Korean elementary, middle, and high schools. ICHPER-SD Journal of Research, 5, 26-32.

Zervas, I.E. (2011). Introduction to motor behavior, psychological approach. Athens: Interbooks.

\footnotetext{
${ }^{\mathrm{i}}$ This book has been translated and edited by Emeritus Professor Ioannis Zervas and published by himself in order to cover the educational needs of the School of Physical Education and Sports Science students (University of Athens).

ii Within the workshops" "space", it is common to hear the phrase "experiential dancer", which is used to emphasise the local roots and "the authenticity" of the instructor, as well as "the authenticity" of the teaching content, insofar as he/she has experienced the local traditions since he/she was a child and, therefore, would transfer them 'unaltered" within the "space" of the workshop.

iii This occurs since through the knowledge of composition rules and principles of Greek traditional dance, that is, the logic that defines its structural composition and style, students learn to construct - during teaching - the motifs and the partial compositions until the full construction of the dance phrase, and, by extent, the choreography of the dance.

iv The only exception is the Department of Physical Education and Sport Science in the University of Athens: students of the major "Greek Traditional Dance", already from the late 90s are taught dance notation and morphology, in order to use the relevant methods and techniques in dance teaching for a creative and student-centred learning.
} 